\title{
Administrative Reforms in the Multilevel System: Reshuffling Tasks and Territories
}

\author{
Sabine Kublmann and Jörg Bogumil
}

\section{INTRODUCTION}

In German administrative federalism, the Länder take the central role as the enforcement level for federal and Land laws (see Chap. 8). Since the post-war period, there have been repeated attempts and initiatives to change, optimise and improve the efficiency of the traditional administrative structure, but hardly ever with decisive success (cf. Ellwein 1994). After German reunification, the East German Länder in particular had to adapt their administrative structures to the West German models (see Chap. 15). Since the beginning of the twenty-first century, however, all Länder governments have intensified their reform efforts with surprising success, measured by the extent and intensity of the changes. The reforms reached their first climax in Baden-Württemberg and Lower Saxony, and then found their way into the majority of German Länder in the form of

\footnotetext{
S. Kuhlmann $(\bowtie)$

University of Potsdam, Potsdam, Germany

e-mail: skuhlman@uni-potsdam.de

J. Bogumil

Ruhr University Bochum, Bochum, Germany

e-mail: joerg.bogumil@rub.de

(C) The Author(s) 2021

S. Kuhlmann et al. (eds.), Public Administration in Germany, Governance and Public Management, https://doi.org/10.1007/978-3-030-53697-8_16
}

271 
territorial and functional reforms (see Ebinger et al. 2018). One major reason for the increasing reform activity is to be found in the precarious situation of the Länder budgets due to escalating pension burdens, demographic developments and debt brakes (see Chap. 14). This situation opened a window of opportunity for governments to push through reforms of their apparatus. Other reasons are ideological or political in nature and are related to governments' ambitions to weaken or dissolve administrative units or levels that are regarded as difficult to control, especially after changes of government.

All Länder are striving to streamline, trim and (partly) concentrate their administrations, albeit with different priorities and instruments. Approaches include the merging of special-purpose authorities at the state government (Länder) level, the dismantling of meso-level state authorities, the decentralisation of state tasks to local governments as well as the rescaling of local governments' territorial boundaries (for a breakdown of administrative levels, see Table 16.1). In Germany, these efforts are often subsumed under the term 'administrative structural reforms' (Verwaltungsstrukturreformen) in a broad all-encompassing sense. Analytically, however, a distinction must be made between three types of reforms: functional reforms, structural reforms and territorial reforms, although these three types are closely interconnected. Functional reforms relate to the reassignment of tasks and responsibilities between existing administrative units and levels (centralisation/decentralisation; concentration/deconcentration). Structural reforms concern the reorganisation of the administrative structures, that is the physical dissolution, merging or creation of administrative units. Finally, territorial reforms refer to a rescaling of counties' and/or municipalities' territorial boundaries. More recently, the latter could only be observed in East Germany, whereas in West Germany territorial reforms were carried out in the 1970s (Thieme et al. 1981; Bogumil 2016; Kuhlmann and Wollmann 2019: 199ff.). The heterogeneity of structural, functional and territorial reforms across the German Länder has led to increasing differences in the institutional settings, task portfolios and organisational frameworks within the administrative federalism at Länder and local level. Accordingly, there is also a high variance regarding the outcomes and impacts of intergovernmental reforms at the subnational level, not only across Länder but also across policy sectors (Kuhlmann et al. 2014; for the evaluation of subnational reforms, see Kuhlmann and Wollmann 2011). 
Table 16.1 Structural and functional reforms in the German Länder (subministerial level)

\begin{tabular}{|c|c|c|}
\hline & $\begin{array}{l}\text { Reforms within two-tier } \\
\text { systems }\end{array}$ & $\begin{array}{l}\text { Reforms within three-tier } \\
\text { systems }\end{array}$ \\
\hline Administrative level & $\begin{array}{l}\text { Brandenburg, Mecklenburg- } \\
\text { Western Pomerania, Lower } \\
\text { Saxony, Saarland, } \\
\text { Schleswig-Holstein }\end{array}$ & $\begin{array}{l}\text { Bavaria, Baden- } \\
\text { Württemberg, Hesse, NRW, } \\
\text { Rhineland-Palatinate, } \\
\text { Saxony, Saxony-Anhalt, } \\
\text { Thuringia }\end{array}$ \\
\hline \multicolumn{3}{|c|}{ State government level (Land administration) } \\
\hline $\begin{array}{l}\text { Upper level } \\
\text { (higher state authorities) }\end{array}$ & $\begin{array}{l}\text { Merging of higher state } \\
\text { authorities; organisational } \\
\text { concentration; } \\
\text { overall institutional } \\
\text { trimming }\end{array}$ & $\begin{array}{l}\text { Integration of (parts of) } \\
\text { higher state authorities into } \\
\text { meso-level instances } \\
\text { (administrative districts); } \\
\text { overall institutional } \\
\text { trimming }\end{array}$ \\
\hline $\begin{array}{l}\text { Meso level } \\
\text { (administrative districts) }\end{array}$ & $\begin{array}{l}\text { not applicable } \\
\text { (no meso-level existent) }\end{array}$ & $\begin{array}{l}\text { Integration of upper- and- } \\
\text { lower level administrative } \\
\text { units; } \\
\text { overall institutional } \\
\text { strengthening }\end{array}$ \\
\hline $\begin{array}{l}\text { Lower level } \\
\text { (lower state authorities) }\end{array}$ & $\begin{array}{l}\text { Merging of lower state } \\
\text { authorities; organisational } \\
\text { concentration; } \\
\text { decentralisation of tasks to } \\
\text { local self-government level; } \\
\text { overall institutional } \\
\text { trimming }\end{array}$ & $\begin{array}{l}\text { Decentralisation to local } \\
\text { self-government level; } \\
\text { centralisation to meso-level } \\
\text { instances; } \\
\text { overall institutional } \\
\text { trimming }\end{array}$ \\
\hline \multicolumn{3}{|c|}{ Local self-government level (counties, county-free cities, municipalities) } \\
\hline $\begin{array}{l}\text { Upper tier } \\
\text { (counties and county-free } \\
\text { cities) } \\
\text { Lower tier } \\
\text { (municipalities) }\end{array}$ & \multicolumn{2}{|c|}{$\begin{array}{l}\text { Integration of tasks transferred by state government } \\
\text { (Länder); partly combined with territorial upscaling; } \\
\text { varying degrees of institutional strengthening } \\
\text { (Limited) Integration of tasks transferred by state } \\
\text { government (Länder); partly combined with territorial } \\
\text { upscaling or increased inter-municipal cooperation; } \\
\text { limited institutional strengthening }\end{array}$} \\
\hline
\end{tabular}

\section{Structural Reforms}

The structural reforms in the German Länder related to a reorganisation of institutional units of the state (Lünder) administration, specifically affecting the meso level, but also parts of the upper-and lower-level state administration. In Germany, the meso-level state administration has the 
traditionally assigned function to bundle and coordinate the various sector-specific administrative activities at sub-state level. The term 'meso level' refers to administrative units located between the ministerial administration at Länder level and the local governments. The bundling function of meso-level state authorities aims at guaranteeing the unity of the state (Land) and a horizontal coordination of various territorially relevant functions at sub-state level (Ellwein 1994). It is intended to limit the fragmentation and dis-connectedness of single-purpose administrative units with different or even conflicting policy responsibilities. Within the federal system of Germany, this function is however organised in very different ways. Some of the German Länder have three-tier systems with a territorial state administration at the meso-level (administrative district authorities), while others-mainly smaller ones-have two-tier systems in which this function is assigned to local self-government (counties). In general, the institutional variance of territorial administration at the meso level in Germany is increasing, in particular as a result of the current structural reforms in the Länder (cf. Kuhlmann and Bogumil 2010; see Table 16.1).

The debate surrounding meso-level instances (administrative district authorities) is first and foremost a question of whether or not a bundling and coordination authority below the ministerial level and above the local government level is required in a specific Land. The main points of criticism of the meso-level authorities refer to their deficits in the fulfilment of coordination and bundling functions. The reasons for these deficits may lie in the fragmentation of the administration-as is evident in the large number of single-purpose authorities - or in the internal structures of the meso-level authorities. The existence of numerous single-purpose authorities at the meso level prevents comprehensive bundling and coordination in administrative district authorities. In addition, this leads to a 'dual administration' consisting of general and specialised authorities at the meso level, such that the same tasks are performed by both a general and a specialist authority, resulting in inefficiency. If-despite the complexity in the thirteen Länder (excluding city-states) — an attempt is made to typify the structural reform approaches at the subnational level in Germany, two models can be distinguished: (1) reforms within or towards two-tier systems; and (2) reforms towards concentrated three-tier systems (see Table 16.1).

(1) A two-tier administration without a general meso-level instance can be found mainly in the small Länder (under three million inhabitants, the exception being Lower Saxony with eight million). Lower Saxony is the 
only German Land that implemented the 'system change' in 2004 from a three-level to a two-level model (Bogumil and Kottmann 2006: 63) by way of dissolving the four administrative district authorities of Brunswick, Hanover, Lüneburg and Weser-Ems and abolishing the administrative districts. This involved an extensive deconcentration of the previously territorially and functionally bundled meso-level state administration and resulted in a significant upgrading of the sectorwise organised specialpurpose Land administration. Accordingly, new attempts are being made in Lower Saxony and in other Länder with two-tier systems to reduce and merge special-purpose Land authorities, integrate them into the higherlevel Land authorities or shift them to local governments.

(2) In most Länder (especially the larger states with the exception of Lower Saxony) a three-tier administration dominates. The lowest level constitutes the counties, the highest level the Land ministries and the meso-level various forms of coordinating and bundling authorities. Institutional bundling of administrative functions as part of a three-level system (ministries, meso-level and counties) is the general model found in the Länder of Bavaria, Hesse, North Rhine-Westphalia, BadenWürttemberg, Saxony, Saxony-Anhalt, Thuringia and RhinelandPalatinate. Among these Länder, three variants of meso-level instances can be distinguished and neither their tasks nor their integration into the administrative structure are uniform nationwide: a) an administrative unit (Landesverwaltungsamt) which assumes coordinating and bundling functions for the whole territory of the Land (Saxony-Anhalt, Thuringia); b) functionally specialised directorates which, in some task areas, are responsible only for specific regions and, in other tasks, for the whole territory of the Land (Rhineland-Palatinate); c) the traditional form of administrative districts which are regionally oriented instances in charge of bundling and coordinating subnational public functions for specific regions within the Land (Hesse, Baden-Württemberg, Bavaria, Saxony ${ }^{1}$ and North RhineWestphalia). In all three models, an attempt is made to achieve a farreaching concentration of state tasks at the meso level, in particular by shifting the tasks of the lower state authorities to the meso level. Moreover, there has been a general attempt to concentrate these duties by privatising existing tasks according to political guidelines or by transferring them to the local government level and realigning some of the authorities.

Baden-Württemberg provides a prime example of this process. The multi-purpose meso-level state administration (administrative district authorities) has been substantially upgraded and functionally 
strengthened since 2005. In addition, numerous state tasks have been transferred to the counties (waiving territorial reforms). The core element of the reform was the complete abolition of 350 out of a total of 450 existing single-purpose state authorities, whose tasks and employees were integrated into the four multi-purpose administrative district authorities and into the thirty-five county administrations and nine county-free cities (Ebinger and Bogumil 2008). The counties received a large number of new responsibilities and emerged from the reform functionally strengthened, even though an increasing number of voices can be heard criticising the new excessive demands being placed on geographically small-scale counties with limited resources (cf. Kuhlmann 2015: 202).

\section{Functional Reforms: Decentralisation of State Tasks}

Another essential feature of the reforms in the multilevel system are functional reforms related to the decentralisation of state tasks to the local governments (also called communalisation). This reform approach aims at transferring tasks typically performed by single-function/special-purpose units of the Land to local self-government (counties/municipalities). It amounts to a strengthening of the multi-purpose organisation at the local level (Kuhlmann 2015: 188ff.). The transfer of state tasks to local authorities can be structured in different legal ways. According to the model of 'genuine municipalisation' (see Kuhlmann and Wollmann 2019: 16lff.) or 'political decentralisation' (Kuhlmann 2015: 187), all functions that are assigned to the local governments become 'real' (genuine) local selfgovernment tasks for which the elected local council is responsible. By contrast, under the model of 'pseudo-' (in lieu of genuine) communalisation (cf. Wollmann 2008: 259ff.) or of 'administrative decentralisation' (Kuhlmann 2015: 187), local governments receive functions that are delegated to them by the state. The responsibility for the conduct of such delegated functions lies with the local government's executive (mayor, head of county administration-Landrat) and not with the elected local council. The transfer of functions in the case of pseudo-communalisation or administrative decentralisation has significant consequences for the municipalities regarding both the internal relations between the local council and local executive and their external relation to the state. First, in the internal relationship, the local executive is solely responsible for the 
implementation of these tasks, while the elected council has, at least formally, no powers. Second, in the external relationship, the local administration is subject to a functional and administrative supervision that goes beyond the legal oversight and that also addresses the merits and adequateness of the activity concerned. By contrast, in cases of genuine communalisation (political decentralisation), the elected local council is, internally, the highest decision-making body, while externally the municipality stands only under the legal oversight of the state authorities. Although in both regards the distinction has often become blurred in local practice, it remains relevant if and when conflicts arise (cf. Wollmann 2008: 259; Kuhlmann and Wollmann 2019: 16lff.). The current functional reforms in Germany primarily correspond to the type of administrative decentralisation (pseudo-communalisation). Most often, local councils are not granted any rights of political decision-making and control regarding the new tasks transferred to them by state governments.

In Germany, the decentralisation of responsibilities is generally viewed positively on the basis of the subsidiarity principle. Indeed, a number of positive effects have been shown, but there are also some sobering empirical findings regarding the outcomes of functional reforms (see Kuhlmann et al. 2014; Kuhlmann 2010,2015). On the one hand, there is a tendency for improved horizontal coordination capacities at the subnational level in Germany, especially after political decentralisation, but less in the case of administrative decentralisation. This seems to prove a general theory in administrative sciences according to which the integration of tasks within multifunctional, politically accountable local governments can help to improve territorial coordination within a given administrative jurisdiction. The reforms also demonstrate that the effectiveness of task fulfilment tends to be positively influenced by political decentralisation.

On the other hand, the euphoric expectations placed upon decentralisation strategies in general cannot be justified by the German experience. Decentralisation often entails considerable additional costs and burdens which sometimes overload local governments. In none of the Länder have state governments shown much inclination to sufficiently address the budgetary problems of local governments by reimbursing costs. Such circumstances frequently increase the risk of default on their performance obligations, implementation failures or inconsistent applications of law. Furthermore, empirical evidence shows that any type of task transfer to lower levels of government exacerbates existing performance disparities or creates new ones. Thus, irrespective of whether a genuine or a 
pseudo-communalisation is pursued, task transfer furthers the interlocal variation and makes the equity of service delivery shrink. It should be emphasised, however, that reform effects are also shaped by other intervening factors, such as the local budgetary and staff situation, policy properties (e.g. person-related vs. technical tasks), local policy preferences and political interests in conjunction with the salience of the tasks transferred.

Against this background, it comes as no surprise that the effects of decentralisation vary greatly across individual municipalities, types of reform policy and fields of activity. Regulatory and technical tasks, such as in the environmental sector as a whole, seem rather unsuitable for decentralisation, while distributive tasks and those heavily reliant on local networking, especially in welfare policies, can benefit from the enhanced local proximity (Kuhlmann et al. 2014; Kuhlmann 2015). It is worth noting that differing or negative reform effects can be seen to result from unresolved interface problems across administrative units, limits in local governments' territorial viability and resources, and the politicisation of newly transferred tasks.

\section{Territorial ReForms}

There is considerable variance across Länder regarding the territorial structure of counties and municipalities (see Chap. 9). Of the 295 counties in Germany, 244 have at least 100,000 inhabitants and more than 100 counties have at least 200,000 inhabitants. The average is 193,000 inhabitants in Western Germany and 162,000 in Eastern Germany. With an average of 95,000 inhabitants, the administrative counties in Thuringia are the smallest in Germany, with ten counties having fewer than 100,000 inhabitants. The total number of inhabitants in Thuringia's counties is about 40 per cent below the average for the eastern German Länder. The same applies to the number of inhabitants in the county-free cities, which are 47 per cent below the average of the eastern Länder and 64 per cent below the average of the western Länder (see Table 16.2). Out of a total of roughly 11,000 municipalities, there is a wide variance in territorial sizes across Länder too. Whereas in North Rhine-Westphalia the average size of the 400 municipalities is 45,000 inhabitants, Rhineland-Palatinate has about 2300 municipalities with 1700 inhabitants on average (see Table 16.3).

Due to the constitutionally entrenched power of the Länder to decide their 'own' territorial reform policy that reflects the different settlement 
Table 16.2 Territorial structures of counties in Germany

\begin{tabular}{|c|c|c|c|}
\hline Land & Number & $\begin{array}{l}\text { Average size } \\
\text { (smallest county-biggest county) }\end{array}$ & \\
\hline Baden-Württemberg & 35 & $\begin{array}{l}247,162 \\
(107,866-531,013)\end{array}$ & $\begin{array}{l}986 \\
(519-1851)\end{array}$ \\
\hline Bavaria & 71 & $\begin{array}{l}125,643 \\
(66,644-329,981)\end{array}$ & $\begin{array}{l}964 \\
(308-1972)\end{array}$ \\
\hline Brandenburg & 14 & $\begin{array}{l}147,077 \\
(77,993-205,520)\end{array}$ & $\begin{array}{l}2054 \\
(1217-3058)\end{array}$ \\
\hline Hesse & 21 & $\begin{array}{l}219,389 \\
(96,201-404,995)\end{array}$ & $\begin{array}{l}971 \\
(222-1848)\end{array}$ \\
\hline $\begin{array}{l}\text { Mecklenburg-Western } \\
\text { Pomerania }\end{array}$ & 6 & $\begin{array}{l}216,915 \\
(155,265-262,412)\end{array}$ & $\begin{array}{l}3812 \\
(2117-5468)\end{array}$ \\
\hline Lower Saxony & 38 & $\begin{array}{l}179,136 \\
(48,670-1,119,526)\end{array}$ & $\begin{array}{l}1223 \\
(535-2882)\end{array}$ \\
\hline North Rhine-Westphalia & 31 & $\begin{array}{l}338,454 \\
(134,947-613,878)\end{array}$ & $\begin{array}{l}980 \\
(407-1960)\end{array}$ \\
\hline Rhineland-Palatinate & 24 & $\begin{array}{l}123,574 \\
(60,765-209,785)\end{array}$ & $\begin{array}{l}783 \\
(305-1626)\end{array}$ \\
\hline Saarland & 6 & $\begin{array}{l}165,120 \\
(88,556-325,978)\end{array}$ & $\begin{array}{l}428 \\
(249-555)\end{array}$ \\
\hline Saxony & 10 & $\begin{array}{l}274,205 \\
(178,346-351,309)\end{array}$ & $\begin{array}{l}1757 \\
(949-2391)\end{array}$ \\
\hline Saxony-Anhalt & 11 & $\begin{array}{l}154,398 \\
(86,312-221,043)\end{array}$ & $\begin{array}{l}1806 \\
(1414-2423)\end{array}$ \\
\hline Schleswig-Holstein & 11 & $\begin{array}{l}200,040 \\
(126,643-301,223)\end{array}$ & $\begin{array}{l}1394 \\
(664-2186)\end{array}$ \\
\hline Thuringia & 17 & $\begin{array}{l}94,868 \\
(57,252-135,155)\end{array}$ & $\begin{array}{l}903 \\
(433-1305)\end{array}$ \\
\hline
\end{tabular}

Source: Authors' own compilation, Federal and Länder Statistical Offices; inhabitants and size as of 31.12 .2016

structures and varying party-political constellations, the reform strategies pursued in Germany show a high amount of variance across the Länder. In procedural terms, the Länder governments carried out their respective reform concepts by inserting a so-called voluntary phase during which municipalities were given the opportunity to 'voluntarily' adjust themselves to the territorial changes proposed. If agreement on the part of the (consulted) municipalities could not be reached, the Land parliament decided as a last resort by way of (binding) Land legislation. 
Table 16.3 Territorial structures of municipalities in Germany

\begin{tabular}{|c|c|c|c|}
\hline State & $\begin{array}{c}\text { Number of } \\
\text { municipalities in total } \\
\text { (December 2017) }\end{array}$ & $\begin{array}{c}\text { Number of } \\
\text { inhabitants in 000's } \\
\text { (December 2018) }\end{array}$ & $\begin{array}{c}\text { Average number of } \\
\text { inhabitants of } \\
\text { municipalities }\end{array}$ \\
\hline Baden-Württemberg & 1101 & 11,070 & 10,054 \\
\hline Bavaria & 2056 & 13,077 & 6360 \\
\hline Brandenburg & 417 & 2512 & 6031 \\
\hline Hesse & 426 & 6266 & 14,708 \\
\hline Mecklenburg- & 753 & 1610 & 2138 \\
\hline \multicolumn{4}{|l|}{ Western Pomerania } \\
\hline Lower Saxony & 945 & 7982 & 8446 \\
\hline North & 396 & 17,932 & 45,282 \\
\hline \multicolumn{4}{|l|}{ Rhine-Westphalia } \\
\hline Rhineland-Palatinate & 2305 & 4085 & 1772 \\
\hline Saarland & 52 & 991 & 19,057 \\
\hline Saxony & 422 & 4078 & 9663 \\
\hline Saxony-Anhalt & 218 & 2208 & 10,128 \\
\hline Schleswig-Holstein & 1110 & 2897 & 2609 \\
\hline Thuringia & 849 & 2143 & 2524 \\
\hline $\begin{array}{l}\text { Federal Republic of } \\
\text { Germany }\end{array}$ & 11,054 & 83,020 & 7510 \\
\hline $\begin{array}{l}\text { West German } \\
\text { Länder (excl. West } \\
\text { Berlin) }\end{array}$ & 8394 & 66,823 & 7997 \\
\hline $\begin{array}{l}\text { East German Länder } \\
\text { (excl. East Berlin) }\end{array}$ & 2659 & 12,551 & 4720 \\
\hline
\end{tabular}

Source: Authors' own compilation, Federal and Länder Statistical Offices

In some of the West German Länder, comprehensive territorial reforms were adopted in the 1970s (see Bogumil 2016). The most radical approaches were pursued in North Rhine-Westphalia and Hesse, which are the most heavily urbanised and densely populated Länder in Germany. These reforms hinged on the amalgamation of all existing municipalities to form new territorially and functionally integrated municipalities. In both these Länder, the number of municipalities was drastically reduced by over 80 per cent. In North Rhine-Westphalia, this resulted in the establishment of newly integrated municipalities with an average of 46,000 inhabitants (see Table 16.3). By contrast, in the majority of Länder, which mostly had more rural areas and were less densely populated, a softer approach was preferred, either by amalgamating only part of the municipalities (e.g. Bavaria) or providing for minimal or practically no 
amalgamation (for instance Rhineland-Palatinate). Furthermore, in those areas with small-sized municipalities, a new level of inter-municipal formations was introduced with the aim of supporting the former in carrying out their functions. The proportion of municipalities that are members of an inter-municipal formation varies between the Länder, reflecting the different impetus of amalgamation. While in Rhineland-Palatinate it is 98.2 per cent, it stands at 47.8 per cent in Bavaria. During the wave of territorial reforms that swept across the (West German) Länder during the 1960s and 1970s, the counties in part went through a radical territorial rescaling by way of amalgamation as well. Nationwide, their total number was cut from 4254 to 237 , which led to an average population size of 600,000 .

The main objectives of the territorial reforms of the 1970s were threefold: (1) to improve local government performance; (2) enhance capacities for fulfilling supra-local objectives, while (3) taking the aspect of proximity to citizens into account (Thieme and Prillwitz 1981: 45). Greater efficiency and cost reduction measures, pursued in the more recent (partly failed) reform attempts (see Kuhlmann et al. 2018a, b), were not regarded as the main goals at the time. As a result of the 1970s reforms, local government performance is better today. Above all, their capacity to offer services has improved, as confirmed by international experience (cf. Kuhlmann et al. 2018a, b with further references). Furthermore, the reforms led to a withdrawal of locally operating administrative units from the territory to institutional concentration, specialisation and professionalisation. As a consequence, it also led to a certain loss of territorial proximity and local political identity. The specialisation and professionalisation positively impacted the quality of service delivery, as it was now possible to maintain and expand certain services. However, there was a need for an institutional counterbalance to concentration and upscaling. A number of administrative units were thus deconcentrated and localised with the aim of bundling together the locally less specialised tasks and services that had direct contact with citizens. The lessons from this reform period are an emphasis on greater proximity to citizens, downscaling of complex tasks to municipalities and upscaling more specialised functions to centralised administrative units supported by efficient ICT (cf. Thieme and Prillwitz 1981). These lessons, however, were barely taken into consideration in the more recent (partly failed) reform debates, which focussed more on reducing costs and increasing efficiency (Kuhlmann et al. 2018a, b) (Table 16.4). 
Table 16.4 Territorial reforms in the West German Länder

\begin{tabular}{lcccc}
\hline Land & $\begin{array}{c}\text { Number of } \\
\text { municipalities } \\
1968\end{array}$ & $\begin{array}{c}\text { Number of } \\
\text { municipalities } \\
1978\end{array}$ & $\begin{array}{c}\text { Number of } \\
\text { municipalities } \\
2017\end{array}$ & $\begin{array}{c}\text { Reduction } \\
(\%)\end{array}$ \\
\hline $\begin{array}{l}\text { Rhineland- } \\
\begin{array}{l}\text { Palatine } \\
\text { Schleswig- }\end{array}\end{array}$ & 2905 & 2320 & 2305 & 21 \\
$\begin{array}{l}\text { Holstein } \\
\text { Bavaria }\end{array}$ & 1378 & 1132 & 1110 & 19 \\
$\begin{array}{l}\text { Lower Saxony } \\
\text { Baden- }\end{array}$ & 7077 & 2056 & 2056 & 71 \\
$\begin{array}{l}\text { Württemberg } \\
\text { Hesse }\end{array}$ & 3379 & 1030 & 945 & 78 \\
Saarland & 2684 & 1111 & 1101 & 67 \\
$\begin{array}{l}\text { North } \\
\text { Rhine- }\end{array}$ & 2277 & 426 & 426 & 84 \\
Westphalia & & 52 & 52 & 86 \\
\hline
\end{tabular}

Source: Authors' own compilation based on Bogumil (2016: 22), updated

Since the early 1990s, the East German Länder have witnessed a proliferation of territorial reforms. The need to amalgamate local governments in these Länder derives from the fact that after reunification the newly established municipalities were organised into small-scale units, which could not live up to the demands of the growing portfolio of tasks emerging at the local level-let alone those tasks to be transferred from state administration (see Chap. 15). After the first wave of consolidation in the mid-1990s, the already difficult situation of several public budgets intensified due to structural weaknesses and the debt cap imposed by the EU. This situation led to a second wave of territorial reforms in 2007 in Saxony, Saxony-Anhalt and Mecklenburg-Western Pomerania. This strong reform momentum has since come to a halt with the current reform attempts in the Länder of Brandenburg and Thuringia. While the early reforms were often carried out by reform coalitions striving for administrative sustainability and competitiveness of their region, the new deliberations alone have become the plaything of political confrontation (see also Ebinger et al. 2018).

The situation of the Land of Brandenburg is an exemplary case. The population will shrink by about 10 per cent by 2030 and the average age will rise further, while the population density will develop more and more 
asymmetrically as a function of the distance to Berlin. Consequently, maintaining infrastructure and services will become a challenge in most parts of the country. The cross-party study commission set up in preparation for the reform of the administrative structure concluded that a territorial reform at county level is indispensable. While the appraisals were similar across Eastern Germany, the set of reform ventures vary considerably concerning drivers (big or small coalition), scope (only county level or municipal-though with time offset), target figures set, actual territorial changes achieved as well as related decentralisation processes (see above).

In Saxony-Anhalt, a territorial reform was executed at both the county and the municipal level. Following the first county-level territorial reform of 1994, the Land Parliament introduced further changes in 2007 under the auspices of the Christlich Demokratische Union Deutschlands (CDU) and the Sozialdemokratische Partei Deutschlands (SPD). The number of counties was reduced from twenty-one to eleven with an average of 153,000 inhabitants (ranging from 86,000 to 223,000 in 2015) and covering an area between $1400 \mathrm{~km}^{2}$ and $2400 \mathrm{~km}^{2}$. The three county-free cities were maintained. At the municipal level, two reforms succeeded in 2004 and 2011 . As a result of amalgamation, the number of municipalities decreased by more than 80 per cent, from 1300 (2003) to 218 (2015), which have an average of 11,000 inhabitants.

Similarly, Saxony implemented territorial reforms at both the municipal and the county level. After the first territorial reform at county level from 1994 to 1996 and at municipal level in 1998, the CDU and the SPD approved another reform in 2008. The remaining twenty-two counties were reduced to ten and the seven county-free cities to three. The ten counties had between 200,000 and 355,000 inhabitants in 2012. The counties cover an area between $1400 \mathrm{~km}^{2}$ and $2400 \mathrm{~km}^{2}$, with the exception of one covering $950 \mathrm{~km}^{2}$. At the municipal level, the number of units decreased by voluntary amalgamation from an original 1626 in 1990 to 540 in the first territorial reform of 1998 , and to 426 as of today, while the average number of inhabitants increased to 9500 .

Mecklenburg-Western Pomerania introduced the first county-level territorial reform in 1994. A further reformative attempt in 2007 was thwarted by the Land's constitutional court (Bogumil and Ebinger 2008). However, in 2011 the parliament finally approved a reform with the support of the CDU and the SPD. The result was a merger of twelve counties into six and six county-free cities into two. These new counties cover an area between $2100 \mathrm{~km}^{2}$ and $5400 \mathrm{~km}^{2}$, corresponding to the biggest 
county in the whole of Germany. The population varied between 156,000 and 264,000 in 2012, with an average of 217,000. Mecklenburg-Western Pomerania has not yet carried out any territorial reform at the municipal level.

The Brandenburg Parliament agreed in July 2016 on a blueprint for structural reform of the administration in 2019 in the hands of the SPD and Die Linke (The Left). The reform envisaged there would be a population of at least 175,000 in the counties and 150,000 in the county-free cities by 2030 . A first proposal with scientific backing that put forward merging the fourteen counties to nine and four county-free cities to one (Potsdam) met with strong opposition. Against the reservations of the parliament's study commission, the Ministry of the Interior of the Land Brandenburg was urged into devising a watered-down solution, reducing the number of counties to eleven. However, because of persisting opposition, the county-level territorial reform was finally discarded in November 2017.

In Thuringia, following the first territorial reform at county level in 1994, the SPD, Die Linke and Die Grïnen (the Greens) approved in 2016 a blueprint and an interim law for administrative, functional and territorial reform. The territorial reform envisaged that the number of municipalities would decrease from 850 to 200 and the seventeen counties to eight, with a minimum population of 130,000 at county level and 6000 at municipal level. Of the six county-free cities, only Erfurt and Jena (with more than 100,000 inhabitants) would maintain their status (Bogumil 2016). However, the reformative plans of the Land government met with strong resistance from the opposition and the communal arena. Furthermore, the ratification of the interim law was declared invalid on formal grounds by the Federal Constitutional Court. As a result, the government abandoned the project on 30 November 2017 (Table 16.5).

One might wonder why the more recent territorial reforms in East Germany (Thuringia and Brandenburg) have failed compared to previous reforms in Mecklenburg-Western Pomerania, Saxony, Saxony-Anhalt and West Germany (see above). Here, there are various factors to consider. First, the political constellations have changed. In both Thuringia and Brandenburg, only very narrow parliamentary majorities were in favour of these reforms, while large political coalitions had supported them in the past. Second, the measures for consultation and active citizen participation carried out by the state government in Brandenburg to enhance support for the reforms turned out to be rather dysfunctional. Instead of 
Table 16.5 Territorial reforms in the East German Länder

\begin{tabular}{lcccc}
\hline Land & $\begin{array}{c}\text { Number of } \\
\text { municipalities } \\
1990\end{array}$ & $\begin{array}{c}\text { Number of } \\
\text { municipalities } \\
2001 / 2003\end{array}$ & $\begin{array}{c}\text { Number of } \\
\text { municipalities } \\
2017\end{array}$ & $\begin{array}{c}\text { Reduction } \\
(\%)\end{array}$ \\
\hline $\begin{array}{l}\text { Mecklenburg- } \\
\text { Western }\end{array}$ & 1117 & 994 & 753 & 33 \\
$\begin{array}{l}\text { Pomerania } \\
\text { Saxony-Anhalt }\end{array}$ & 1349 & 1289 & 218 & 84 \\
Thuringia & 1699 & 1017 & 849 & 50 \\
Brandenburg & 1775 & 422 & 417 & 76 \\
Saxony & 1623 & 540 & 422 & 74 \\
\hline
\end{tabular}

Source: Authors' own compilation based on Bogumil (2016: 24), updated

supporting the government's reform agenda, the local governments, mayors and heads of county councils used the direct-democratic participatory arena as a public forum for mobilising protest against the reform. Moreover, the opposition parties (the CDU; the Freie Demokratische Partei, (FDP); and the Alternative für Deutschland (AfD)) allied themselves with the mass media and thus fuelled a highly emotionalised debate impeding any attempt at objective and evidence-based discourse. Finally, the state government overemphasised increases in efficiency as a major reform goal, which, based on earlier reform experience, raised doubts about the expected reform success and sharply contrasted with the previous reforms in West Germany. These reforms were much more guided by policies that aimed at improving local governments' performance and capacities rather than increasing efficiency and reducing costs.

\section{CONClusions ANd LesSONS FOR Transfer}

A good decade after the entry into force of the major reform projects at national level, the administrative landscape in some Länder has undergone fundamental changes (Kuhlmann 2009). The bundling of responsibilities, the dismantling of double administrations, communalisation and territorial reforms are steps in the right direction towards modernising and improving the performance of subnational public administration. In order for these measures to achieve their goals, however, it is vital to ensure that they are used in a prudent and task-oriented manner and not merely as a calculated political manoeuvre or to achieve savings targets. The 
observation of the current administrative reforms makes it clear that, when shifting responsibilities, certain factors must be taken into account (for an international overview see Schwab et al. 2017; Kuhlmann 2010). For instance, factors such as the ability of the municipalities to provide services that are seldom required but demand a high degree of specialisation, the efficiency with which tasks are performed and the uniformity of administrative execution. The particularly pronounced tension between technical and political objectives at this level due to local proximity and the democratic legitimacy of the decision-maker is also an important factor. There is also a close connection between the possibility of functional reforms and the existing territorial structures (Kuhlmann et al. 2018a, b; Ebinger et al. 2018).

In practice, the problem is that in the field of administrative structural reforms, it is not always possible to combine technical arguments, political will and enforceability. It is not surprising that this has never fully been achieved. For example, political decisions made in both the administrative structural reform in Baden-Württemberg and in Saxony could hardly be justified from a technical point of view. However, until 2011 it was possible, at least in large coalitions, to implement (necessary) territorial reforms. In the light of past experience in Thuringia and Brandenburg, there is good reason to be more sceptical here. The majorities in each case were narrow and this certainly made the reforms more difficult. Even the earlier (reform) alliances between the local government associations and the state governments, such as in Saxony, were no longer possible as it was only a question of power. How to combine the positive modernisation will of the state governments with functional and regional reforms and integrating the knowledge of the administration into the process is still an open question and also dependent on political framework conditions. An important lesson to learn from the various waves of (successful and failed) territorial reforms in Germany is that they should not be justified mainly by the argument of increasing efficiency, but of improving local governments' capacities and performance instead. The latter effects of territorial upscaling are well documented in literature and supported by empirical findings, while greater efficiency and cost savings through mergers have not generally been recorded as they largely depend on specific context conditions and local implementation processes (cf. Kuhlmann et al. 2018a; for the conceptual background see Kuhlmann and Wollmann 2011).

A major strength of the German administrative system is that it promotes territorial and functional variations, which allow for flexible models 
of subnational intergovernmental organisation. This variety of institutional set-up and reform approaches encourages piloting, adjustments and learning. However, different models can lead to differences in service provision, treatment of citizens and varying institutional progress of local administration. Furthermore, a balance needs to be found between 'too small' and 'too big' territorial jurisdictions. A continuous monitoring of local governments' service quality and performance seems indispensable for identifying new reform requirements in due time and for adjusting institutional settings accordingly. Many of the organisational features and reform approaches discussed here make perfect sense in the German politico-administrative context. They constitute domestic institutional responses to context-specific problems agreed upon by state and local actors. Given such particularities, any possible transfer of the German institutional solutions described in this chapter should be approached with caution, and the respective country-specific political, administrative and cultural circumstances should be taken into consideration when drawing on lessons and translating concepts.

\section{Note}

1. The three administrative districts were renamed Landesdirektionen in 2008. On 1 March 2012, these were formally merged into one regional directorate (which continues to have regional branches).

\section{REFERENCES}

Bogumil, J. (2016). Nengliederung der Landkreise und kreisfreien Städte in Thüringen. Gutachten im Auftrag des Thüringer Ministeriums für Inneres und Kommunales. Bochum: Ministry of Interior Thuringia.

Bogumil, J., \& Ebinger, F. (2008). Machtgewinn der Kommunen? In C. Büchner, J. Franzke \& M. Nierhaus (Eds.), Verfassungsrechtliche Anforderungen an Kreisgebietsreformen (pp. 13-23). Zum Urteil das Landesverfassungsgerichtes Mecklenburg-Vorpommern, $S$.

Bogumil, J., \& Kottmann, S. (2006). Verwaltungsstrukturreform in Niedersachsen. Die Abschaffung der Bezirksregierungen (Publication Series of the Stiftung Westfalen-Initiative, vol. 11). Münster: Ibbenbürener Vereinsdruckerei.

Ebinger, F., \& Bogumil, J. (2008). Grenzen der Subsidiarität. Verwaltungsreform und Kommunalisierung in den Ländern. In H. Heinelt \& A. Vetter (Eds.), Lokale Politikforschung heute (pp. 165-196). Wiesbaden: VS Verlag für Sozialwissenschaften. 
Ebinger, F., Bogumil, J., \& Kuhlmann, S. (2018). Territorial Reforms in Europe: Effects on Administrative Performance and Democratic Participation. Local Government Studies, 45(1), 1-23. https://doi.org/10.1080/0300393 0.2018 .1530660 .

Ellwein, T. (1994). Das Dilemma der Verwaltung: Verwaltungsstruktur und Verwaltungsreform in Deutschland. Mannheim: BS-Taschenbuchverlag.

Kuhlmann, S. (2009). Reforming Local Government in Germany: Institutional Changes and Performance Impacts. German Politics, 18(2), 226-245. https:// doi.org/10.1080/09644000902870842.

Kuhlmann, S. (2010). Between the State and the Market: Assessing Impacts of Local Government Reforms in Western Europe. Lex localis-Journal of Local Self-Government, 8(1), 1-21. https://doi.org/10.4335/8.1.1-21(2010).

Kuhlmann, S. (2015). Administrative Reforms in the Intergovernmental Setting: Impacts on Multi-Level Governance from a Comparative Perspective. In E. Ongaro (Ed.), Multi Level Governance: The Missing Linkages (Series 'Critical Perspectives on International Public Sector Management', vol. 4) (pp. 183-215). https://doi.org/10.1108/S2045-794420150000004008.

Kuhlmann, S., \& Bogumil, J. (2010). Kommunale Aufgabenwahrnehmung im Wandel: Kommunalisierung, Regionalisierung und Territorialreform in Deutschland und Europa. Wiesbaden: VS-Verlag.

Kuhlmann, S., Bogumil, J., \& Grohs, S. (2014). Reforming Public Administration in Multi-level Systems: An Evaluation of Performance Changes in European Local Governments. In E. Bohne et al. (Eds.), Public Administration and the Modern State. Assessing Trends and Impact (pp. 205-222). Basingstoke: Palgrave Macmillan.

Kuhlmann, S., Siegel, J., \& Seyfried, M. (2018a). Was bewirken Gebietsreformen? Eine Bilanz deutscher und europäischer Erfahrungen. dms-der moderne Staat, 11(1), 119-142. https://doi.org/10.3224/dms.vllil.08.

Kuhlmann, S., Siegel, J., \& Seyfried, M. (2018b). Wirkungen kommunaler Gebietsreformen: Stand der Forschung und Empfehlungen für Politik und Verwaltung. Berlin: Nomos/Ed. Sigma.

Kuhlmann, S., \& Wollmann, H. (2011). Special Issue on Evaluating Functional and Territorial Reforms in European Countries. Local Government Studies, 35(5).

Kuhlmann, S., \& Wollmann, H. (2019). Introduction to Comparative Public Administration: Administrative Systems and Reforms in Europe (2nd ed.). Cheltenham and Northampton: Edward Elgar.

Schwab, C., Bouckaert, G., \& Kuhlmann, S. (Eds.). (2017). The Future of Local Government in Europe: Lessons from Research and Practice in 31 Countries. Berlin: Nomos/Ed. Sigma. https://doi.org/10.5771/9783845280639.

Thieme, W., \& Prillwitz, G. (1981). Durchführung und Ergebnisse der kommunalen Gebietsreform. Baden-Baden: Nomos. 
Thieme, W., Unruh, G. von, \& Scheuner, U. (1981). Die Grundlagen der kommunalen Gebietsreform. Baden-Baden: Nomos.

Wollmann, H. (2008). Reformen in Kommunalpolitik und -perwaltung. England, Schweden, Frankreich und Deutschland im Vergleich. Wüstenrot Stiftung. Wiesbaden: VS Verlag für Sozialwissenschaften.

Open Access This chapter is licensed under the terms of the Creative Commons Attribution 4.0 International License (http://creativecommons.org/licenses/ by $/ 4.0 /$ ), which permits use, sharing, adaptation, distribution and reproduction in any medium or format, as long as you give appropriate credit to the original author(s) and the source, provide a link to the Creative Commons licence and indicate if changes were made.

The images or other third party material in this chapter are included in the chapter's Creative Commons licence, unless indicated otherwise in a credit line to the material. If material is not included in the chapter's Creative Commons licence and your intended use is not permitted by statutory regulation or exceeds the permitted use, you will need to obtain permission directly from the copyright holder.

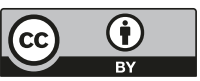

